\title{
The Effect of Problem Based Learning Model based on SAVI toward Student Higher Order Thinking Skills and Science Process Skills at Coordination System Subject in SMA Negeri 1 Aek Kuo
}

\author{
$1^{\text {st }}$ Zaria Triana Wahyuningtyas ${ }^{1}, 2^{\text {nd }}$ B. Manurung ${ }^{2}, 3^{\text {rd }}$ K. Lubis ${ }^{3}$ \\ \{zariadalimunthe@gmail.com ${ }^{1}$, binarimanurung@unimed.ac.id ${ }^{2}$, khairizalubis@unimed.ac.id ${ }^{3}$ \} \\ Post graduate Program, Universitas Negeri Medan, Indonesia ${ }^{1}$, Department of Biology, Universitas \\ Negeri Medan, Indonesia ${ }^{2}$, Department of Biology, Universitas Negeri Medan, Indonesia ${ }^{3}$
}

\begin{abstract}
This research aimed to determinate the effect of PBL based on SAVI toward Higher Order Thinking Skills and Science Process Skills at Coordination System Subject in SMA Negeri 1 Aek Kuo. A quasi experimental research used a randomized pretestposttest control group design. The sampling technique was total sampling, namely experiment class 1 using PBL model based on SAVI, experiment class 2 using PBL model, and experiment class 3 using conventional. The number of samples was 69 students. The techniques test was used in data collection. Higher order thinking skills and science process skill were analyzed by covariate analysis (Anacova) and further Tukey's test with a significant level $\alpha=0,05$. Anacova results showed that there was significant effect by the PBL model based on SAVI, PBL, and conventional toward higher order thinking skills $(\mathrm{F}=12,61 ; \mathrm{P}=0,000)$ and science process skills $(\mathrm{F}=11,70 ; \mathrm{P}=0,000)$. The posttest average of student higher order thinking skills and science process skills with PBL based on SAVI was higher compared to PBL and conventional learning.
\end{abstract}

Keywords: PBL based.on SAVI, PBL, Higher Order Thinking Skills, Science Process Skills.

\section{Introduction}

Biology is one of the most important branches of science especially in human life, because biology has made a great contribution to the sustainability of human life. However, it is unfortunate that the importance on this knowledge is not accompanied by learning activities that is oriented to students' process skills at school.

The facts in studying science showed that students tend to memorize concepts, theories, and principles without interpreting the process of acquisition. Learning is more directed towards the success of taking exams which essentially emphasizes lower cognitive domains such as memorizing concepts, understanding, and applying formulas, while higher cognitive processes (analyzing, evaluating, and creating) are rarely used. In addition, the aspect of student activity itself has been neglected, as well as process skills and their application in daily life [2].

One of the problems faced in the world of education is the weakness of the learning process. Learning which is generally carried out by teachers emphasizes more on aspects of 
knowledge and understanding, while aspects of application, analysis, synthesis, and even evaluation are only a small part of the learning. The learning is still teacher-oriented and students are not given the opportunity to develop thinking skills. Learning with direct instruction model causes students to be less active in learning. The use of this model does not involve students in teaching and learning activities because the activities are still centered on the teacher. Learning is directed at memorizing and hoarding information, so that students are theoretically smart. Students have not been involved to think about dealing with problems that occur in daily life. These cases are in line with the problems that occurred in SMA Negeri 1 Aek Kuo, North Labuhanbatu Regency.

SMA Negeri 1 Aek Kuo is located in Padang Halaban, Aek Kuo Dictrict, North Labuhanbatu Regency. Based on the results of the interview, SMA Negeri 1 Aek Kuo is included in the 3T (Terdepan, Terluar and Tertinggal) which means Front, Outermost, and Disadvantaged school. Therefore, learning innovations are needed to help the implementation of the learning process, especially in learning biology.

In general, coordination system subject is understood by students only through the description of the concept. This learning process resulted in students less understanding of the relationship between the concepts learned in daily life, resulting in low high-level thinking skills and scientific processing skills. The results of observations and interviews with biology teachers at SMA Negeri 1 Aek Kuo, North Labuhanbatu Regency showed that learning outcomes are still low. This is evidenced by the acquisition of the student scores below the minimum criteria of mastery learning (KKM).

One of the things that is expected to be able to overcome the problems in biology learning is the application of the Problem Based Learning (PBL) model, where this model expected students to be able to find their own problems, interested in solving these problems by finding solutions of the problems. [1] The results of showed that Problem Based Learning (PBL) is able to improve students' critical thinking skills. [6] The SAVI and PBL learning models are able to improve students' critical thinking skills. The PBL model provides opportunities for students to explore in the learning process. In addition to improving process skills in groups, an approach is needed that can support individual student learning styles.

Learning style is a combination of how a person absorbs, and then organizes and processes the information he receives [3]. The results of the observations obtained that students are still indifferent, less focused, not paying the attention, and sleepy which shows the low skills of students in learning. Low student skills have an impact on low students' learning outcomes. Students need an approach that can support student learning styles that are still less varied. One such style is SAVI (Somatic Auditory Visual Intellectual).

The SAVI approach is a natural way of learning that includes somatic, meaning learning by moving. Auditory is learning by speaking and listening. Visual means learning to observe and describe. Intellectual is learning by solving problems and explaining. Previous research has argued that the SAVI approach is a learning approach that involves the senses, learns to be physically active, and involves the whole body or mind involved in the learning process [4]. The use of this approach involves students to be active in learning which is expected to improve students' science process skills. 


\section{Method}

This research was conducted at SMA Negeri 1 Aek Kuo, North Labuhanbatu Regency, from March to June 2021. The population of this study were 11th grade students of SMA Negeri 1 Aek Kuo, totaling 69 students who were divided into 3 classes. The sample of this study were obtained from total population of students who have 3 classes, where the first experimental class was taught by the PBL based on SAVI model, the second experimental class used the PBL model and the third class used conventional learning as a controlled class. The independent variable in this study was learning using PBL based on SAVI, PBL, and conventional PBL models. The dependent variable in this study was higher order thinking skills and science process skills. This research belongs to quasi-experimental research, with the research design in the form of a randomized pretest-posttest control group design.

The test was used to collect the data in this research. For the test of students' higher-order thinking skills, the researchers prepared in the form of multiple choice questions with five choices totalling 40 questions. Meanhile, the Science Process Skills consisted of 9 questions covering the ability to describe the results of observations, classify, predict, interpret, ask questions, plan experiments, apply concepts, and communicate results.

The parametric inferential analysis was used in data analysis. The data is analyzed for normality test (Komolgorov Smirnov test) and homogeneity test (Levene's Test) before conducting data analysis. Inferential data analysis technique was used to test the research hypothesis by using the anacova test at a significance level of $=0.05$. Data were analyzed using SPSS 21.0.

\section{Results and Discussion}

\subsection{Students' Pretest (Higher Order Thinking Skills)}

The students' pretest higher order thinking skills were described in Table 1.

Table 1. Description of Students' Pretest.

\begin{tabular}{lccc}
\hline \multirow{2}{*}{ Statistic scores } & \multicolumn{3}{c}{ Classes } \\
\cline { 2 - 4 } & Conventional & PBL & PBL based on SAVI \\
\hline Max Score & 55.00 & 95.00 & 82.50 \\
Min Score & 20.00 & 17.50 & 15.00 \\
Average & 31.84 & 37.48 & 40.11 \\
Standard Deviation & 8.46 & 16.46 & 19.22 \\
Total Students & 23 & 23 & 23 \\
\hline
\end{tabular}

\subsection{Students' Posttest (Higher Order Thinking Skills)}

The students' posttest higher order thinking skills were described in Table 2. 
Table 2. Description of Students' Posttest.

\begin{tabular}{lccc}
\hline \multirow{2}{*}{ Statistic scores } & \multicolumn{2}{c}{ Classes } \\
\cline { 2 - 4 } & Conventional & PBL & PBL based on SAVI \\
\hline Max Score & 95.00 & 92.50 & 95.00 \\
Min Score & 20.00 & 22.50 & 45.00 \\
Average & 45.48 & 50.87 & 73.83 \\
Standard Deviation & 22.99 & 20.28 & 14.07 \\
Total Students & 23 & 23 & 23 \\
\hline
\end{tabular}

\subsection{Students' Pretest (Science Process Skills)}

The students' pretest science process skills were described in Table 3.

Table 3. Description of Students' Pretest.

\begin{tabular}{lccc}
\hline \multirow{2}{*}{ Statistic scores } & \multicolumn{3}{c}{ Classes } \\
\cline { 2 - 4 } \multicolumn{1}{c}{ Conventional } & PBL & PBL based on SAVI \\
\hline Max Score & 63 & 40 & 43 \\
Min Score & 40 & 63 & 63 \\
Average & 50.17 & 52.96 & 54.39 \\
Standard Deviation & 4.77 & 5.69 & 4.95 \\
Total Students & 23 & 23 & 23 \\
\hline
\end{tabular}

\subsection{Students' Posttest (Science Process Skills)}

The students' posttest science process skills were described in Table 4.

Table 4. Description of Students' Posttest.

\begin{tabular}{lccc}
\hline \multirow{2}{*}{ Statistic scores } & \multicolumn{3}{c}{ Classes } \\
\cline { 2 - 4 } & Conventional & PBL & PBL based on SAVI \\
\hline Max Score & 85.00 & 88.00 & 90.00 \\
Min Score & 58.00 & 73.00 & 76.00 \\
Average & 73.17 & 81.09 & 81.65 \\
Standard Deviation & 7.65 & 5.17 & 5.10 \\
Total Students & 23 & 23 & 23 \\
\hline
\end{tabular}

\subsection{The Effect of PBL Model based on SAVI toward Student Higher Order Thinking Skills}

Based on the research result, learning model was shown a significant effect toward higher order thinking skills by hypothesis test of covariance analysis (Anacova) with a value of $(\mathrm{F}=12.61 ; \mathrm{P}=0.000)$. Hence, there was a significant effect toward higher order thinking skills. It indicated that a statement from Ha, which said that PBL learning model based on SAVI had an effect toward student higher order thinking skills in 11th grade students of SMA Negeri 1 Aek Kuo, was accepted. In addition, a study comparison test was conducted to find out how big the effect of learning model was. Based on the result of Tukey's test, the higher order 
thinking skills with PBL model based on SAVI had $\mathrm{X}^{-} \pm \mathrm{SD}(73,83 \pm 14,07)$ higher than the higher order thinking skills with PBL model had $X^{-} \pm \operatorname{SD}(50,87 \pm 20,27)$ and conventional learning had $\mathrm{X}^{-} \pm \mathrm{SD}(45,48 \pm 22,99)$.

The further results of Tukey's test, overall, toward student higher order thinking skills in conventional, experiment class 1, and experiment class 2 were provided in Figure 1.

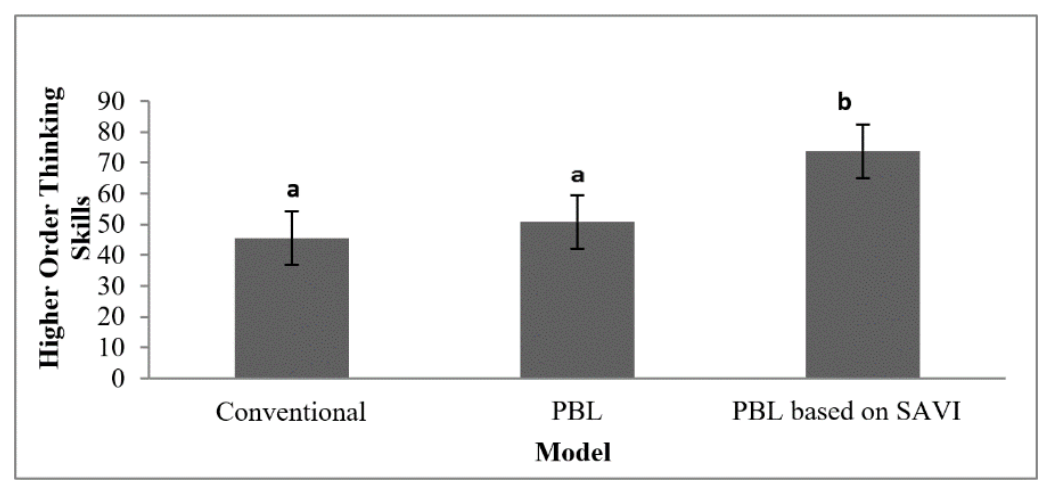

Fig. 1. The differences of higher order thinking skills taught by PBL model based on SAVI, PBL model, and conventional were shown in the figure above. The different significances were indicated by the same letter.

\subsection{The Effect of PBL Model Based on SAVI toward Student Science Process Skills}

The effect of PBL model based on SAVI toward student science process skills was analyzed by covariance analysis (Anacova). The effect of learning model toward student science process skills with a value of $(\mathrm{F}=11.692 ; \mathrm{P}=0.000)$ was shown significantly by the analysis result.

Therefore, there was a significant effect of learning model toward student science process skill. Thus, Ha which stated that there was an effect of PBL model based on SAVI toward student science process skills in 11th grade students of SMA Negeri 1 Aek Kuo was accepted. A study comparison test was additionally conducted to find out how big the effect of learning model toward science process skills was.

Science process skills taught by PBL model based on SAVI having $\mathrm{X}^{-} \pm$SD 81,65 \pm 22,98 higher compared to science process skills taught by SAVI model having $\mathrm{X}^{-} \pm$SD 81,09 $\pm 20,27$ and conventional learning having $\mathrm{X}^{-} \pm$SD 73,17 $\pm 14,07$ were shown by Tukey's test results. Science process skills taught by PBL model based on SAVI and SAVI model were higher significantly than conventional learning.

The further results of Tukey's test, overall, toward student science process skills in conventional, experiment class 1, and experiment class 2 were provided in Figure 2. 


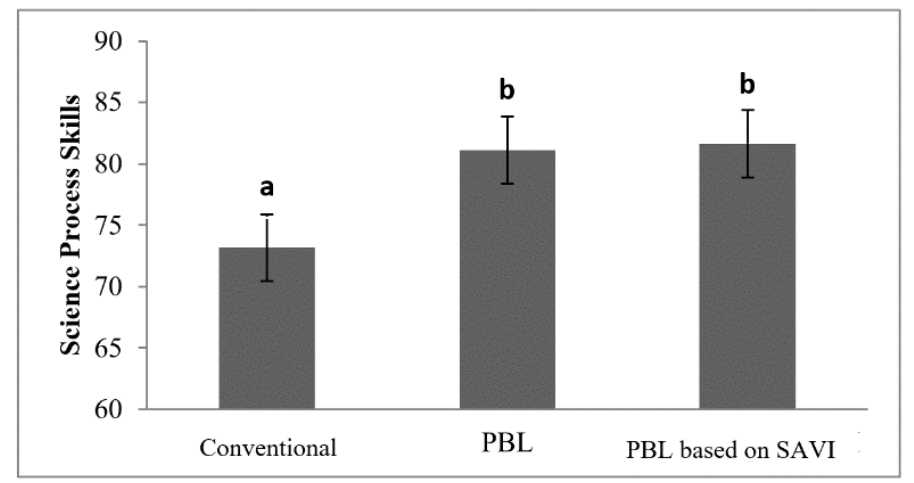

Fig. 2. The differences of science process skills taught by PBL model based on SAVI, PBL model, and conventional were shown in the figure above. The different significances were indicated by the same letter.

\subsection{The Effect of PBL Model Based on SAVI toward Student Higher Order Thinking Skills}

The significant differences between PBL experiment based on SAVI, PBL, and conventional toward student higher order thinking skills were indicated by the research and hypothesis test results where PBL model based on SAVI had higher average than conventional. Thus, probability value of 0,000 , which stated Ho was rejected and Ha was accepted, was shown by posttest using Anacova. Hence, there were difference averages in higher order thinking skills between conventional, experiment class 1, and experiment class 2 .

During learning process in experiment class 1 and experiment class 2, the material was discussed by students in groups. The learning process in experiment class 1 with SAVI model was commenced with delivering the material by the teacher as students' initial understanding concept toward the discussed material. Learning model consisted of heterogeneous group in which there were sections of material to be discussed to develop mastery and skill from each group member to create positive dependency.

Problem based learning empowers students to gain new knowledge and understanding through various achievements. In addition, [5] problem based learning is a great opportunity for students to hone students' hands-on discovery of real world problems.

The various learning styles were supported by PBL model based on a good teamwork with SAVI approach. Students that could express their various learning styles were given by applying the SAVI approach. It was supported which stated that an approach based on activity (BBA), which means physically activity, makes the whole parts of the body and thought involved in the learning process. The combinations of physical movement and intellectual activity and the use of students' sense to increase motivation and student outcomes are called SAVI approach [7].

Different from conventional which used direct instruction learning model, the learning process was more controlled by the teacher so students were more passive because it placed students as a listener and note-taker. It was an accordance with a theory that a weakness of direct instruction learning model is that not all students have skills to listen, observe, and note well [8]. 
Based on the processed, analyzed, and discussed data above, it can be concluded that there were effects of the application of SAVI learning model and cooperative PBL type based on SAVI toward student higher order thinking skills.

\subsection{The Effect of PBL Model Based on SAVI toward Student Science Process Skills}

The significant differences between PBL model based on SAVI, PBL, and conventional were indicated by the research and hypothesis test results where student science process skills taught by PBL model based on SAVI were higher compared to students taught by PBL model and class taught by conventional. Therefore, Ha was accepted and Ho was rejected. Thus, it could be concluded that there were significant effect between PBL model based on SAVI, PBL, and conventional toward student science process skills in 11th grade students of SMA Negeri 1 Aek Kuo.

Student science process skills taught by PBL model based on SAVI were higher than PBL model and conventional. It was in accordance with a research stating that there are significant effects in learning toward student science process skills. Besides, it was that students taught by PBL model based on SAVI have higher science process skills than students taught by PBL model and conventional.

Based on the research results, student science process skills taught by PBL model based on SAVI were significantly different from student science process skills taught by PBL and conventional model. It was because PBL model based on SAVI is a model using a project or activity as a media and using the project and activity as the media in doing activity for real and giving an opportunity to students to dig deeper into the material by using various method which meant for themselves and doing activity collaboratively.

\section{Conclusion}

Based on the results and discussion in this research, it is concluded that: (1) There is a significant effect of PBL model based on SAVI, PBL, and conventional toward student higher order thinking skills in SMA Negeri 1 Aek Kuo. (2) There is a significant effect of PBL model based on SAVI, PBL, and conventional toward student science process skills in SMA Negeri 1 Aek Kuo.

\section{References}

[1] Arnyana IBP. Pengaruh Penerapan Model PBL Dipandu Strategi Kooperatif Terhadap Kecakapan Berpikir Kritis SMA Pada Mata Pelajaran Biologi. J Pend dan Pengajaran IKIP Negeri Singaraja. $2005 ; 4: 1-5$

[2] Depdiknas. Undang-Undang No.20 Tahun 2003 Tentang Sistem Pendidikan Nasional. Jakarta: Depdiknas; 2003.

[3] Deporter B. Quantum Learning: Membiasakan Belajar Nyaman Dan Menyenangkan. Penerjemah Alwiyah Abdurrahman. Bandung: Kaifa; 2011.

[4] Dewi A. Penerapan Pendekatan SAVI (Somatis, Auditori, Visual Dan Intelektual) Untuk Meningkatkan Minat Belajar Dan Pemahaman Konsep Matematika Siswa Kelas VIII. Yogyakarta: Universitas Negeri Yogyakarta; 2011. 
[5] Ellis TJ, Hafner W. Building A Framework to Support Project- Based Collaborative Learning Experience in An Asynchronous Learning Network (ALN). Interdiciplinary J of E-Learning and Learning Objects. 2008; 4:168-189.

[6] Mazaly MR. Pengaruh Model Pembelajaran Problem Based Learning Terhadap Kemampuan Pemecahan Masalah Matematis. J Pend, Matematika dan Sains. 2021: 5(2):179-190.

[7] Sari W. Pengaruh Pendekatan SAVI (Somatic, Auditory, Visual, And Intelectual) dengan menggunakan Media Education Card Terhadap Pemahaman Siswa). J Ilmiah Mahasiswa. 2017: 1 (4):108-113.

[8] Suprihatiningrum J. Strategi Pembelajaran: Teori Dan Aplikasi. Yogyakarta: Ar Ruzz Media; 2013. 